Portland State University

PDXScholar

\title{
Differential Health and Social Needs of Older Adults Waitlisted for Public Housing or Housing Choice Vouchers
}

\author{
Paula C. Carder \\ Portland State University, carderp@pdx.edu \\ Gretchen Luhr \\ Portland State University \\ Jacklyn Nicole Kohon \\ Portland State University, jacklynk@pdx.edu
}

Follow this and additional works at: https://pdxscholar.library.pdx.edu/aging_pub

Part of the Gerontology Commons, Urban Studies Commons, and the Urban Studies and Planning Commons

Let us know how access to this document benefits you.

\section{Citation Details}

Carder, Paula C.; Luhr, Gretchen; and Kohon, Jacklyn Nicole, "Differential Health and Social Needs of Older Adults Waitlisted for Public Housing or Housing Choice Vouchers" (2016). Institute on Aging Publications. 21.

https://pdxscholar.library.pdx.edu/aging_pub/21

This Post-Print is brought to you for free and open access. It has been accepted for inclusion in Institute on Aging Publications by an authorized administrator of PDXScholar. Please contact us if we can make this document more accessible: pdxscholar@pdx.edu. 


\title{
Differential health and social needs of older adults waitlisted for public housing or housing choice vouchers
}

\author{
Paula Carder \\ Portland State University, PO Box 751, Portland, Oregon, UNITED STATES,97207 \\ Gretchen Luhr \\ Institute on Aging, Portland State University, UNITED STATES \\ Dr Jacklyn Kohon \\ Institute on Aging, Portland State University, UNITED STATES
}

\section{Abstract}

Affordable housing is an important form of income security for low-income older persons. This article describes characteristics of older persons waitlisted for either public housing or a housing choice voucher (HCV) (previously Section 8) in Portland, Oregon. 358 persons (32\% response rate) completed a mailed survey with questions about demographics, health and housing status, food insecurity, and preference for housing with services. Findings indicate that many waitlisted older persons experienced homelessness or housing instability, poor health, high hospital use, and food insecurity. Public housing applicants were significantly more likely to report lower incomes, homelessness, and food insecurity than HCV applicants. We conclude with policy implications for housing and health agencies that serve low-income older persons.

Keywords: waiting list, health status, elderly, poverty, housing policy 
Access to affordable housing is a concern for older persons, especially the 4.2 million individuals, or 9.5\% of all elderly, whose incomes are below poverty level (Administration on Aging (AoA, 2014). The annual income of older renters $(\$ 17,300)$ is half that of homeowners (AoA, 2014); low-income renters have less stable housing compared to low-income homeowners (Corporation for Enterprise Development, 2015). Housing is a social determinant of health (Krieger \& Higgins, 2002) for older persons with multiple chronic health conditions, mobility impairments, and limited social supports (Alley et al., 2009; Waldbrook, 2013). The relationship between health, housing, and poverty is evident in disability prevalence among older persons. Over half of renters age 65 and older have a disability (Harrell, 2011), and 38\% of tenants in Section 202 units, a Department of Housing and Urban Development (HUD) program for persons age 62 and older, could be at-risk for institutionalization (Haley \& Gray, 2008). The incidence of homelessness among persons age 62 and older is projected to double between 2010 and 2050 from 44,172 to over 95,000 persons (Sermons \& Henry, 2010).

Two major forms of publicly-subsidized rental assistance for low-income older persons include apartment units and housing choice vouchers (HCV, also called Section 8). An estimated 1.3 million older persons receive publicly subsidized rental assistance (LeadingAge, 2011), and 37\% of the nearly five million households that receive HUD-assisted housing are headed by a person age 62 or older (Locke, Lam, Henry, \& Brown, 2011). In 2012, 30\% of householders in public housing were age 65 or older, as were $46 \%$ of Project-Based Section 8 (designated for elderly and disabled) housing residents (National Low Income Housing Coalition [NLIHC], 2012). Forty-five percent of tenants in privately-owned HUD-subsidized properties (including Section 
202) were 65 or older (HUD, 2008). In contrast, older persons account for only $21 \%$ of all HCV users (Center for Budget and Policy Priorities, 2015).

Public housing benefits may include resident services staff who provide information and referral, and convenient locations, although public housing is associated with concentrated poverty and stigma (Vale \& Freemark, 2012). In comparison, housing choice vouchers might provide applicants a wider range of housing types and neighborhoods. However, adults with mobility problems may have difficulty using a HCV because doing so requires the applicant to locate rental properties that meet their needs, pass a required HUD inspection, and accept below market rate rents (Cremin, 2000; Finkel \& Buron, 2001; McFadden \& Lucio, 2014; Popkin, Cunningham, \& Burt, 2010). Economic forces such as low vacancy and high market rates present challenges to HCV holders who must compete with persons who pay market rates (Finkel \& Buron, 2001). However, federal housing policy decisions promote public-private market strategies, such as HCVs and tax-credit financing, and limit reliance on public housing complexes (Popkin et al., 2010; Sard \& Alvarez-Sanchez, 2011; Vale \& Freemark, 2012).

Large numbers of people have either applied for rental housing assistance and been placed on a waiting list or were discouraged from applying because waiting lists exceeded availability (Quigley, 2008). Vacancy rates for subsidized housing units are very low-less than 3\% in Section 202 and just under 10\% among all affordable housing units (Kochera, 2006). Waiting lists for a Section 202 apartment average at least one year (Vandawalker, Locke, \& Lam, 2012); there are 50 applicants waiting for a Section 202 unit and 38 applicants for an LIHTC property 
(Kochera, 2006). Section 202 units become available due to tenant death or nursing facility admission (Haley \& Gray, 2008).

Despite the numbers of older persons waiting for rental assistance in the U.S., this population is nearly invisible. Studies in Australia, Canada, and Europe report that older persons apply for publicly subsidized housing because they have health problems and lack informal supports and because public housing provides access to shops and public transportation (Burke, Neske, \& Ralston, 2005; Prescott-Clarke, Clemons, \& Park, 1994; Smith \& Sylvestre, 2008; van Bilsen, Hamers, Groot, \& Spreeuwenberg, 2006). One U.S. study of nonelderly, nondisabled applicants reported homelessness, rent burden and poor housing quality among waitlisted persons (Leopold, 2012). The present study sought to fill the gap in knowledge about older waitlisted applicants of rental assistance.

\section{Methods}

As an exploratory study, the primary aim was to describe the characteristics of older applications. An additional analytic goal was to compare the status of applicants for public housing versus HCVs because the limited research to date suggests that older adults or persons with disabilities might have more difficulty using a HCV. We surveyed all persons age 55 and older who applied for and were waitlisted for a HCV or a unit in one of four public housing properties designated for elderly and disabled and owned by the Portland, Oregon public housing authority. The survey and overall study design were approved by the [ANONYMOUS] Human Subjects Research Review Committee. 


\section{Sample}

A total of 1,331 waitlisted applicants were identified in August 2011. Of those applicants, 933 had signed up for public housing and 417 for HCV (some individuals applied for both). The income eligibility for both programs was the same. Surveys were mailed in housing authority envelopes with a letter on [ANONYMOUS] letterhead that explained the study purpose, confidentiality, and that some surveys would be eligible for a random drawing for a ten dollar gift card. A stamped return envelope was addressed to [ANONYMOUS]. Of the 1,331 mailed letters, 150 were non-deliverable and 54 were duplicates, reducing the sample to 1,127 . In total, 358 surveys were received for a 31.7\% response rate. Although a postcard reminder or re-mailed survey might have increased the response rate, the limited budget prevented this method. Of the 358, 233 applied for public housing, 118 for HCV, and 7 for both programs. Because the analyses compare applicants by program type, the 7 who applied to both were excluded.

To assess possible differences between respondents and non-respondents, the two groups were compared by housing application type (e.g., public housing, HCV). T-tests for independence revealed no significant differences.

\section{Survey}

Survey items included questions about demographics, current housing status, future housing preference, health status, food insecurity, and use of safety net programs. To compare differences by demographic characteristics, questions asked about age, place of birth, gender, race and ethnicity, preferred language, marital status, and individual income. 
Current housing status was assessed by asking whether the respondent currently lived alone, with others, or identified as homeless; length of residence at current home; type of lease; monthly rent; and experience with homelessness. One question asked whether the respondent had applied to properties not owned by the housing authority.

Future housing preference was assessed with questions adapted from two earlier surveys of people waitlisted for public housing (Prescott-Clarke et al, 1994; Pynoos, Reynolds, Salend, \& Rahman, 1995). Questions included current wish to move, reasons for wanting to move, preference for age-restricted housing (age 55 and older), and preference for housing with on-site services such as meals and housekeeping.

Health items were assessed with a self-rated health measure with a five-point scale (excellent to poor) (Kaplan \& Comacho, 1983). Additional health status items included whether in the prior 12 months the respondent had a major medical illness, been hospitalized overnight, or visited the emergency room (yes/no); and received assistance (yes/no) with instrumental activities of daily living (IADLs) or activities of daily living (ADLs; bathing, dressing and grooming). To identify the availability of informal support, we asked whether a friend, relative or neighbor "could assist you for a few days if necessary?” (yes/no).

Food insecurity in the prior 30 days was assessed using two items modified from the Household Food Security Survey (Bickel, Nord, Price, Hamilton \& Cook, 2000): “Have you been concerned about having enough food to eat?" and "Have you eaten less than you felt you should because there wasn't enough money to buy food?” A third question assessed the link between food access and mobility (“Have you ever been hungry but didn’t eat because you weren’t able to get out for 
food?"), because older persons are more likely than younger persons to have mobility impairments (Chung, Gallo, Giunta, Canavan, Parikh, \& Fahs, 2012; Wolfe, Frongillo, \& Valois, 2003). The food security questions used a yes/no response format. If respondents indicated 'yes' to at least one of the three food security items, they were deemed to be 'food insecure'.

To assess use of safety net programs, questions about medical insurance (lack of insurance in prior 12 months, type of health insurance coverage) and use of Supplemental Nutrition Assistance Program (SNAP, or food stamps) benefits (yes/no) were asked.

\section{Data Analysis}

Survey data were first entered in a database and a 10\% sample was checked for data entry errors; mistakes were adjusted accordingly. SPSS was used to analyze the survey data. Analyses included cross-sectional associations between demographic characteristics and waitlist typepublic housing or voucher. The $\chi^{2}$ test was used for descriptive comparisons between the two groups. T-tests for independence were used to test for differences on any continuous variables (e.g., age and monthly rent). The sample was 351; cases were excluded from analyses where data were missing. The tables report findings based on applicant type (public housing vs. HCV). 


\section{Results}

\section{Demographic Characteristics}

There were few significant differences on demographic characteristics when comparing public housing to HCV respondents (Table 1). Differences existed in comparing English as a preferred language and annual incomes less than $\$ 10,000$, such that public housing applicants were more likely to report preferring English as a primary language and having annual incomes less than $\$ 10,000$. An independent samples t-test indicated $(t=-3.79, p<.001)$ that public housing applicants tended to be younger than HCV respondents.

\section{TABLE 1}

\section{Current Housing Status and Wish to Move}

More than half (54\%) of the respondents reported living alone, however there were no significant differences between those in public housing and HCV respondents in their current living arrangements (see Table 2). Approximately 8\% identified as currently homeless. There were differences between public housing and HCV respondents on the length of the time that they have been in their current housing. Fifty-eight percent reported that they had applied only to the housing authority (rather than a private, non-profit housing agency), though $14 \%$ were not sure whether they had applied to other housing providers ('not sure' response excluded from analysis). Nearly two-thirds of all respondents either had no lease or paid rent on a month-tomonth basis. The average monthly rent currently paid by respondents was approximately $\$ 397$ 
$(\mathrm{SD}=\$ 285)$, though public housing applicants paid less than current HCV applicants $(\mathrm{t}=-2.83$, $\mathrm{p}<.005)$. Although few of these items reached statistical significance, they provide a useful portrait of rental assistance applicants.

Respondents were asked about their current wish to move (see Table 2). Only a small number no longer wanted to move (9\%), and the majority wanted to move in the next year (33\%), with over one-fourth wanting to move in the next month (27\%), and about one-fifth not certain when they would want to move (21\%). Statistically significant differences existed within the current wish to move.

Of the 329 persons who answered the question about whether they would prefer to live in an apartment building designated for persons age 55 and older; approximately $47 \%$ wanted to do so (see Table 2). Public housing respondents were significantly more likely to report they preferred senior housing with services as compared to HCV respondents.

\section{INSERT TABLE 2}

\section{Health and Housing Risk Vulnerability}

The majority of respondents (57\%) described their health as fair or poor, and nearly half (48\%) had a major medical illness in the past 12 months, and $47 \%$ visited the ER, and over one-quarter (28\%) had been hospitalized overnight (see Table 3).

Several survey items were grouped based on social determinants of health: individual income under $\$ 10,000$ annual, prior homelessness, currently homeless, food insecurity, recent 
medical illness and/or hospital use, lack of health insurance, fair/poor self-rated health, over age 75, living alone, and female. The two applicant groups were similar in terms of living alone and being female, but for several categories, there were differences between applicants for public housing and HCVs. More public housing applicants had annual incomes of less than $\$ 10,000$ (p $<.001)$, experienced homeless within the prior 12 months $(\mathrm{p}<.001)$, reported food insecurity ( $\mathrm{p}$ $<.05)$, and lacked health insurance within the prior 12 months $(\mathrm{p}<.05)$. While only 31 respondents were older than 75 years, more were HCV residents $(\mathrm{p}<.01)$.

\section{INSERT TABLE 3}

These analyses indicate that public housing applicants differ from HCV applicants, with the public housing respondents scoring worse on some measures that represent health and housing risk and vulnerability.

\section{Supportive Services and Public Benefits}

Most respondents had a source of social support available to assist if needed (63\%). HCV respondents were more likely to report the availability of both family and neighbors as sources of assistance as compared to public housing respondents (Family: $\chi^{2}=4.45, \mathrm{p}<.05$; Neighbors: $\chi^{2}$ $=4.47, \mathrm{p}<.05)$ (not shown).

About $28 \%$ of respondents reported receiving assistance with one or more of the following IADLs, in rank order: shopping for food or other items, going to places outside the home, household cleaning/maintenance, laundry, food preparation, using the telephone or computer, and medication management (not shown). A small percentage (10\%) of persons received 
assistance with activities of daily living (ADLs) such as bathing, dressing, or grooming. There were no discernible differences in IADL/ADL assistance between public housing and HCV waitlist applicants. The majority of respondents received food stamps (70\%; not shown).

\section{Multivariate Findings}

We identified variables for inclusion in a regression model based on the above analyses, topics of interest to policy makers, and the outcome of interest - application to either public housing or HCV. All variables were entered simultaneously. Respondents with incomes less than $\$ 10,000$ per year were more than three times more likely to apply for public housing as compared to HCV $(\mathrm{b}=1.21, \mathrm{OR}=3.34, \mathrm{p}<.001)$; and respondents who spoke English as a primary language were more than twice as likely to opt for public housing $(\mathrm{b}=.93$, OR $=2.53, \mathrm{p}<.05)$. As compared to respondents who desired to move within a month, those who wanted to move within the year (b $=-.95, \mathrm{OR}=.39, \mathrm{p}<.05)$ and those who were undecided about moving $(\mathrm{b}=-.88, \mathrm{OR}=.42, \mathrm{p}<$ .05) were less likely to opt for public housing (see Table 4). The multiple logistic regression had good model fit $\left(\chi^{2}=44.2\right)$ in predicting application type. The Nagelkerke $\mathrm{R}^{2}$ indicates that the model predictors account for about $24 \%$ of the difference in housing application waitlist type.

\section{INSERT TABLE 4}

\section{Study Limitations}

Although this survey was mailed to all individuals age 55 and older who applied for one of four public housing properties or HCV, the respondents do not necessarily represent all older persons 
on these or other waiting lists. From a demographic perspective, the sample included a higher percentage of women, mostly single or widowed, White, and U.S. born adults who live alone. The survey was available in English only, so individuals who do not read English might be under-represented. Currently homeless applicants were likely missed, although 8\% of respondents identified as currently homeless. Waiting lists were not available for properties financed with other public subsidies (e.g., LIHTC), therefore the findings may not represent older applicants for other types of rent-subsidized housing.

\section{Discussion}

To our knowledge, this paper reports the first survey of older persons waitlisted for rental assistance in the U.S. in 20 years (Pynoos et al., 1995). Rental assistance offers financial security to persons with low incomes (Leopold, 2012). Public housing and HCVs prioritize individuals with very low incomes $-30 \%$ of area median income ( $\$ 15,450$ for a single household in 2015). However, subsidized housing provides more than affordable rent; applicants may also seek health-related and social supports (Golant, 2003). The observed differences between applicants for public housing and HCVs, and the finding that a significant percentage of applicants report health and social problems, provides a basis for conceptualizing the relationship between health and housing. We conclude with implications for affordable housing with service programs. 


\section{Access to Affordable Housing}

Housing access is a matter of social equity because access is unfairly distributed and may result in extreme deprivation, morbidity, and mortality (Shaw, 2004). Many publicly-funded programs, such as Medicaid and SNAP, base access on eligibility criteria; once those criteria are verified, the applicant may use the benefit. In contrast, publicly-financed rental assistance uses a "sweepstakes" rather than an "eligibility" model of aid in which applicants who meet eligibility thresholds receive the benefit only after their number is called, usually because they rose to the top of the waiting list (Quigley, 2010). Nationally, less than one-third of all renters with incomes below 30\% of local median income receive housing assistance (Quigley, 2008).

Housing agencies must manage their waitlists, most often using a first-come, first-served method as the primary management tool (HUD, 2013). Theories of individual and system-level factors assume that there is a rational queuing system for goods or services and that individual or system issues prevent the queue from functioning properly, but Pope (1991) maintains that these explanations fail to capture the dynamic and interpersonal nature of waiting list creation and management. Instead, we must examine the context of waiting lists by researching waitlisted applicants and housing agency policies. Our finding that $67 \%$ of applicants had applied to more than one list suggests that applicants may try to 'hedge their bets,' though we lack information about how and why older persons apply to different agencies. Future research should collect information from agencies that rental assistance applicants. 


\section{Housing and Health}

This study provides evidence that many older applicants for rental assistance have significant health issues. Likely some of older adults seek housing assistance because of their poor health. Interestingly, the finding that respondents who wanted to move with a sense of urgency (i.e., within a month) were more likely to apply for public housing as opposed to a HCV (Table 4) is important as it may reflect ease of system navigation and fewer access barriers compared to HCVs. In addition, this finding supports other research that aging in place might not be desirable, or possible, for low-income older adults (Byrnes, 2011).

Based on Chi-square analyses, public housing applicants fair worse than HCV applicants on several measures (income, homeless in prior 12 months, food insecure, and lacking health insurance), and were significantly less likely to report the availability of informal support. These analyses found that health, rather than older age, is associated with applicants' preference for public housing over a HCV and that respondents with a recent major medical illness and/or who recently used the hospital were more likely to prefer age-restricted housing. The observation that regression analyses did not support these variables as predictive of applicant type suggests that more research, using a larger sample and with a greater response rate, is needed.

The finding that poor health—as indicated by presence of a recent major medical illness and hospital use-is more likely to be associated than older age with preference for age-restricted housing with services suggests that some applicants seek housing because they need help with daily activities. Collaboration among housing agencies and health agencies—such as accountable care organizations (ACO) — might benefit currently waitlisted applicants (Erickson \& Andrews, 
2011). For example, an ACO could identify whether it covers applicants and then assess whether applicants' have prioritized health-related risks (e.g., frequent hospitalizations).

\section{Housing with Services: Policy Implications}

Housing, health and social service agencies are coordinating service delivery to affordable housing residents to extend and support aging in place (Cotrell \& Carder, 2010; Harahan, Sanders \& Stone, 2006; Lawler, 2001; Locke et al, 2011; Pynoos, Nishita, Cicero, \& Caraviello, 2008). While housing with services programs have positive outcomes for current residents (Siu, 2009), they might limit low-income older persons' access to affordable housing by extending current residents' tenure and reducing the supply of available units. Housing with services policies that support aging in place must be weighed against the needs of waitlisted applicants. Affordable housing with service programs with inter-agency collaborations (LeadingAge, 2011) might extend services from current residents to housing applicants.

In conclusion, significant numbers of older persons waiting for public housing and/or HCVs report poor health, housing instability, hospital use, food insecurity, and very low incomes. These individuals look to housing assistance as a potential source of support, even though such housing typically provides only minimal health-related supports.

Housing authorities must manage their waiting lists, including targeting individuals who are at high risk of homelessness or negative outcomes associated with specific medical conditions (Pearson, Montgomery \& Locke, 2009). To identify those at highest risk, and to effectively target resources, both housing and aging service planners require more information about the 
characteristics of persons on waiting lists for rental assistance. If a partnership of housing agencies were to create a central data set of waitlisted applicants, it would benefit local agencies and low-income older adults who have unmet housing, health and social needs. Public housing authorities could consider creating a single waitlist for both public housing and HCVs that would allow applicants the choice of either form of rental assistance. This approach should not penalize an applicant on the public housing waitlist who accepts a voucher but prefers to remain on the list for a suitable housing unit that is not yet available. A review of waitlist policies used by Section 202 and project-based Section 8 properties is recommended.

Finally, the differential health and social needs of public housing and HCV applicants must be explored to assess how these differences account for disparities in access to housing and health services. Such information can inform whether housing agencies should prioritize affordable housing or HCVs, both of which are inadequate to meet demand, and guide decisions about waitlist management.

\section{References}

Administration on Aging. (2014). A Profile of Older Americans. Washington, DC: Author. Retrieved from http://www.aoa.acl.gov/Aging_Statistics/Profile/2014/docs/2014-Profile.pdf

Alley, D.E., Soldo, B.J., Pagán, J.A., McCabe, J., deBlois, M., Field, S.H., Asch, D.A., \& Cannuscio, C. (2009). Material resources and population health: Disadvantages in health care, housing, and food among adults over 50 years of age. American Journal of Public Health, 99(S3), S693-S701. 
Bickel G, Nord M, Price C, Hamilton WL, Cook J. (2000). Guide to measuring household food security. Alexandria, VA: U.S. Department of Agriculture, Food and Nutrition Service, Office of $\begin{array}{llll}\text { Analysis, Nutrition } \quad \text { and } & \text { Evaluation. }\end{array}$ http://www.fns.usda.gov/sites/default/files/FSGuide.pdf

Burke, T., Neske, C., \& Ralston, L. (2005). Entering rental housing. Melbourne, Victoria: Australian Housing and Urban Research Institute. Retrieved from http://www.ahuri.edu.au/publications/projects/p50142

Byrnes, M. E. (2011). A city within a city: A "snapshot" of aging in a HUD 202 in Detroit, Michigan. Journal of Aging Studies, 25(3), 253-262.

Center for Budget and Policy Priorities. (2015). Policy basics: the Housing Choice Voucher program. Washington, DC: Author. Retrieved from http://www.cbpp.org/research/housing/policy-basics-the-housing-choice-voucher-program

Chung, W.T., Gallo, W.T., Giunta, N., Canavan, M.E., Parikh, N.W., \& Fahs, M.C. (2012). Linking neighborhood characteristics to food insecurity in older adults: The role of perceived safety, social cohesion, and walkability. Journal of Urban Health, 89(3), 407-18.

Corporation for Enterprise Development. (2015). Assets and opportunity scorecard: Housing cost burden. Washington, D.C. Retrieved from http://assetsandopportunity.org/scorecard/

Cotrell, V. \& Carder, P.C. (2010). Health-related needs assessment of older residents in subsidized housing. Cityscape, 12(2); 47-66.

Cremin, K.M. (2000). The transition to Section 8 housing: Will the elderly be left behind? Yale Law \& Policy Review, 18, 405-429. 
Erickson, D., \& Andrews, N. (2011). Partnerships among community development, public health, and health care could improve the well-being of low-income people. Health Affairs, 30(11), 2056-2063.

Finkel, M. \& Buron, L. (2001). Study on Section 8 voucher success rates. Washington, D.C.; Housing and Urban Development.

Golant, S. M. (2003). Political and organizational barriers to satisfying low-income U. S. seniors' need for affordable rental housing with supportive services. Journal of Aging \& Social Policy, 15(4), 21-48.

Haley, B. A. \& Gray, R.W. (2008). Section 202 supportive housing for the elderly: Program status and performance measurement. U.S. Department of Housing and Urban Development Office of Policy Development and Research. Retrieved from http://www.huduser.org/Publications/pdf/sec_202_1.pdf

Harahan, M., Sanders, A., \& Stone R. (2006). Creating new long-term care choices for older adults: A synthesis of findings from a study of affordable housing plus services linkages. Washington, DC: Institute for the Future of Aging Services.

Harrell, R. (2011). Housing for older adults: The impacts of the recession. Washington, DC: AARP Public Policy Institute. Retrieved from: http://assets.aarp.org/rgcenter/ppi/livcom/insight53.pdf

HUD: U.S. Department of Housing and Urban Development. (November, 2013). HUD Handbook 4350.3: Occupancy requirements of subsidized multifamily housing programs. U.S. 
Department of Housing and Urban Development. Retrieved from http://portal.hud.gov/hudportal/documents/huddoc?id=43503HSGH.pdf

HUD Office of Policy Development and Research (2008). Characteristics of HUD assisted renters and their units in 2003. Washington, DC: HUD. Retrieved from http://www.huduser.org/portal/publications/pdf/Hud_asst_renters_report_p1.pdf

Kaplan, G. A. \& Camacho, T. (1983). Perceived health and mortality: A nine-year follow-up of the human population laboratory cohort. American Journal of Epidemiology, 117(3):292-304.

Kochera, R. (2006). Developing appropriate rental housing for low-income older persons: A survey of Section 202 and LIHTC property managers. Washington, DC: AARP PPI. Retrieved from http://www.aarp.org/home-garden/housing/info-2006/dd149_lihtc.html

Krieger, J. \& Higgins, D. L. (2002). Housing and health: Time again for public health action. American Journal of Public Health, 92(5), 758-768. doi: 10.2105/AJPH.92.5.758.

Lawler, K. (2001). Aging in place: Coordinating housing and health care provision for America's growing elderly population. Joint Center for Housing Studies, Graduate School of Design and John F. Kennedy School of Government, Harvard University.

LeadingAge (2014). Picture of housing and health: Medicare and Medicaid use among older adults in HUD-assisted housing. Washington, DC: ASPE. Retrieved from http://aspe.hhs.gov/basic-report/picture-housing-and-health-medicare-and-medicaid-use-amongolder-adults-hud-assisted-housing\#intro

LeadingAge. (May, 2011). Summit on aging in place in public housing. Washington, DC: Author. Retrieved from 
http://www.leadingage.org/uploadedFiles/Content/About/Center_for_Applied_Research/Expandi ng_Affordable_Housing_Plus_Services/Public_Housing_Authority_Summit.pdf

Leopold, J. (2012). The housing needs of rental assistance applicants. Cityscape 14(2), 275-298.

Locke, G., Lam, K., Henry, M., \& Brown, S. (February, 2011). End of participation in assisted housing: What can we learn about aging in place? Wahsington, DC: Department of Housing and Urban Development, Office of Policy Research and Development. Retrieved from http://www.huduser.org/publications/pdf/Locke_AgingInPlace_AssistedHousingRCR03.pd $\underline{\mathrm{f}}$

McFadden, E. S., \& Lucio, J. (2014). Aging in (privatized) places: Subsidized housing policy and seniors. Journal of Housing for the Elderly, 28(3), 268-287.

National Low Income Housing Coalition. (2012). Who lives in federally assisted housing? Housing Spotlight, 2(2), 1-4.

Parsons, P. L., Mezuk, B., Ratliff, S., \& Lapane, K. L. (2011). Subsidized housing not subsidized health: health status and fatigue among elders in public housing and other community settings. Ethnicity \& Disease, 21(1), 85.

Pearson, C, Montgomery, A.E., \& Gretchen Locke, G. (2009). Housing stability among homeless individuals with serious mental illness participating in housing first programs. Journal of Community Psychology, 37, 404-417.

Pope, C. (1991). Trouble in store: some thoughts on the management of waiting lists. Sociology of Health \& Illness, 13, 193-212. 
Popkin, S.J., Cunningham, M.K., \& Burt, M. (2010). Public housing transformation and the hard-to-house. Housing Policy Debate, 16(1), 1-24.

Prescott-Clarke, P., Clemens, S., \& Park, A. (1994). Routes into local authority housing: a study of local authority waiting lists and new tenancies. London, England: HMSO, Department of the Environment.

Pynoos, J., Nishita, C., Cicero, C., \& Caraviello, R. (2008). Aging in place, housing, and the law. Elder Law Journal, 16(1), 77-105.

Pynoos, J., Reynolds, S.L., Salend, S., \& Rahman, A. (1995). Waiting for federally assisted housing: A study of the needs and experiences of older applicants. Washington, DC: AARP.

Quigley, J. M. (2010). Rental housing assistance. Cityscape, 13(2), 147-158.

Quigley, J. M. (2008). Just suppose: Housing subsidies for low-income renters. Boston, MA: Joint Center for Housing Studies, Harvard University. Retrieved from http://www.jchs.harvard.edu/sites/jchs.harvard.edu/files/rr07-9_quigley.pdf

Sard, B. \& Alvarez-Sanchez, T. (December, 2011). Large majority of housing voucher recipients work, are elderly, or have disabilities. Washington, DC: Center on Budget and Policy Priorities. Retrieved from http://www.cbpp.org/research/large-majority-of-housing-voucher-recipientswork-are-elderly-or-have-disabilities

Sermons, M.W. and Henry, M. (April, 2010). Demographics of homelessness series: The rising elderly population. Washington, DC: National Alliance to End Homelessness. Retrieved from http://www.endhomelessness.org/library/entry/demographics-of-homelessness-series-the-risingelderly-population 
Shaw, M. (2004). Housing and public health. Annual Review of Public Health, 25, 397-418.

Siu, C. (2009). Impacts of nutrition and human services interventions on the health of elderly and disabled persons in public housing. Washington, DC: Congressional Hunger Center. Retrieved from http://www.hungercenter.org/wp-content/uploads/2011/07/Impacts-NutritionHuman-Services-Elderly-Disabled-in-Public-Housing-Siu.pdf

Smith, G. C., \& Sylvestre, G. M. (2008). Effects of neighborhood and individual change on the personal outcomes of recent movers to low-income senior housing. Research on Aging, 30(5), 592-617.

Vale, L. J., \& Freemark, Y. (2012). From public housing to public-private housing: 75 Years of American social experimentation. Journal of the American Planning Association, 78(4), 379402.

van Bilsen, P. A., Hamers, J. H., Groot, W. W., \& Spreeuwenberg, C. C. (2006). Demand of elderly people for residential care: An exploratory study. BMC Health Services Research, 639-9. doi:10.1186/1472-6963-6-39.

Vandawalker, M., Locke, G., \& Lam, K. (2012). Evaluation of the Section 202 Demonstration Predevelopment Grant Program. Washington, DC: HUD. Retrieved from http://www.huduser.org/Publications/pdf/HUD-493_Section_202.pdf

Waldbrook, N. (2013). Formerly homeless, older women's experiences with health, housing, and aging. Journal of Women and Aging, 25(4), 337-357. doi: 10.1080/08952841.2013.816213

Wolfe, W.S., Frongillo, E.A., Valois, P. (2003). Understanding the experience of food insecurity by elders suggests ways to improve its measurement. Journal of Nutrition 133(9), 2762-2769. 
Table 1. Respondent Characteristics by Application Type

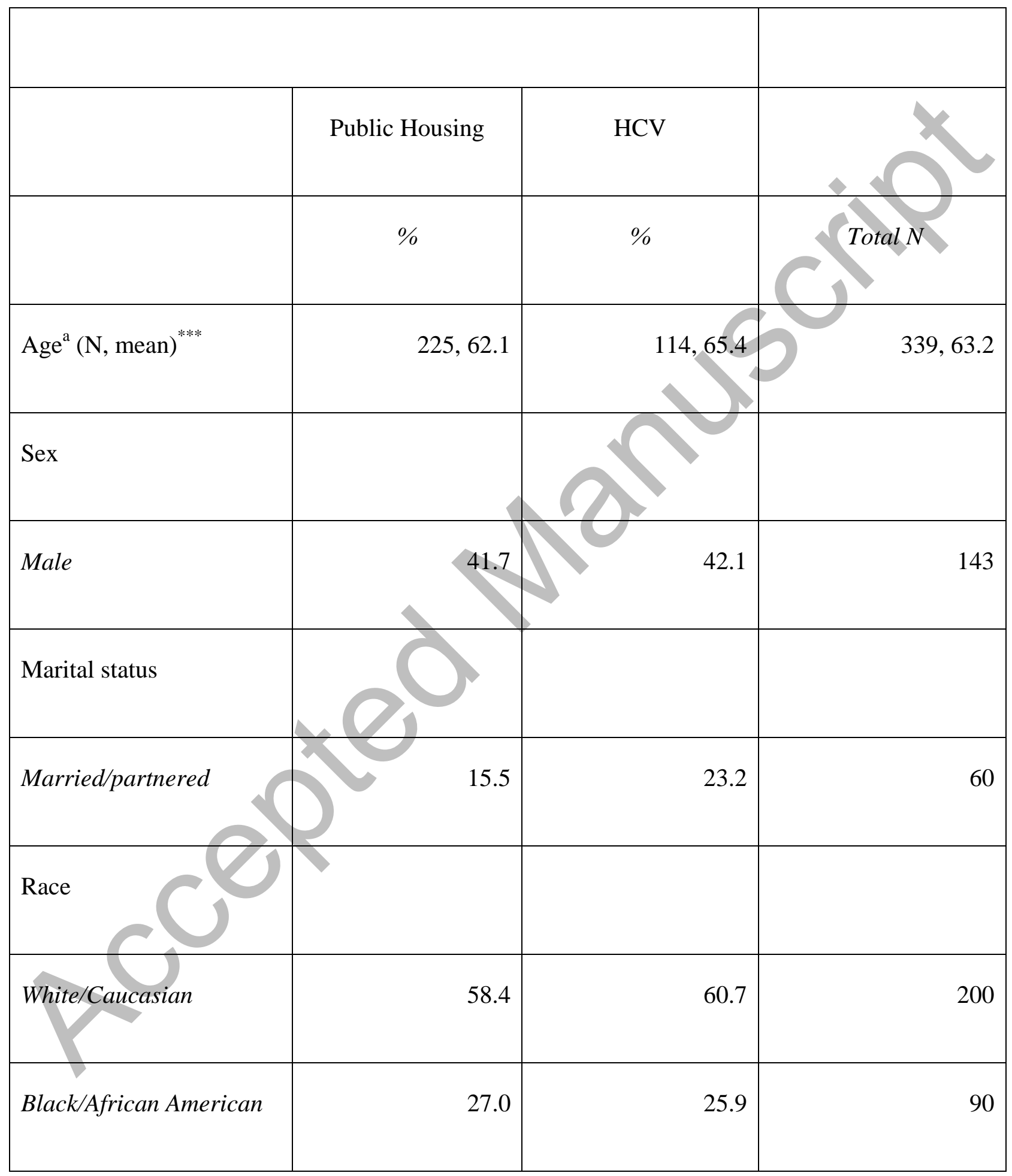




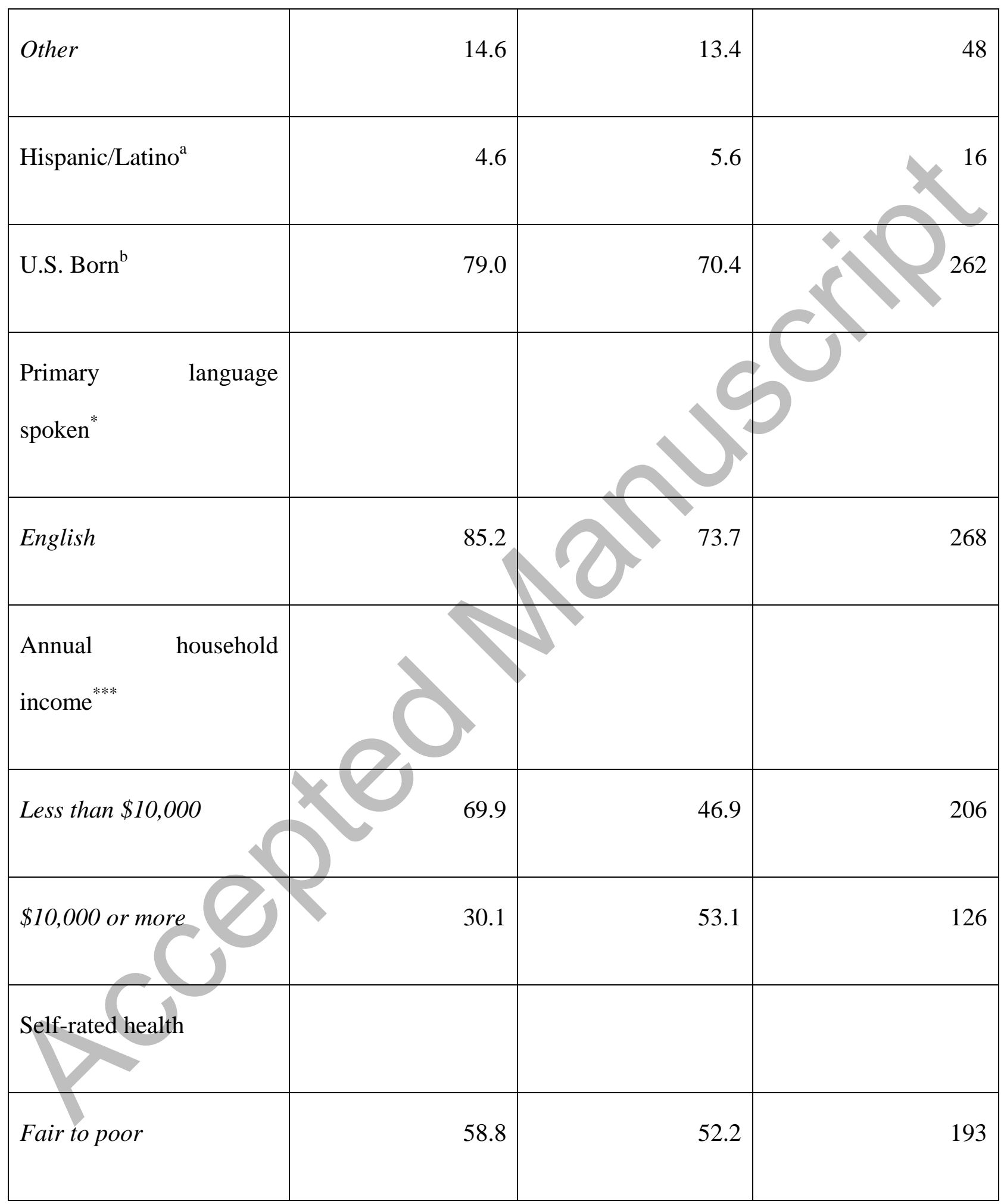




\begin{tabular}{|l|r|r|r|}
\hline Excellent to good & 41.2 & 47.8 & 148 \\
\hline
\end{tabular}

${ }^{*} \mathrm{p}<.05 .{ }^{* * *} \mathrm{p}<.001$.

${ }^{\mathrm{a}} \mathrm{SD}$, min/max: PH (6.5, 55-86); HCV (8.9, 55-96); total (7.5, 55-96)

'Percentages based on respondents who said 'Yes' as compared to respondents who reported 'No' for each item. Percentage 'No' not reported. 
Table 2. Current Housing Status and Current Wish to Move by Application Type

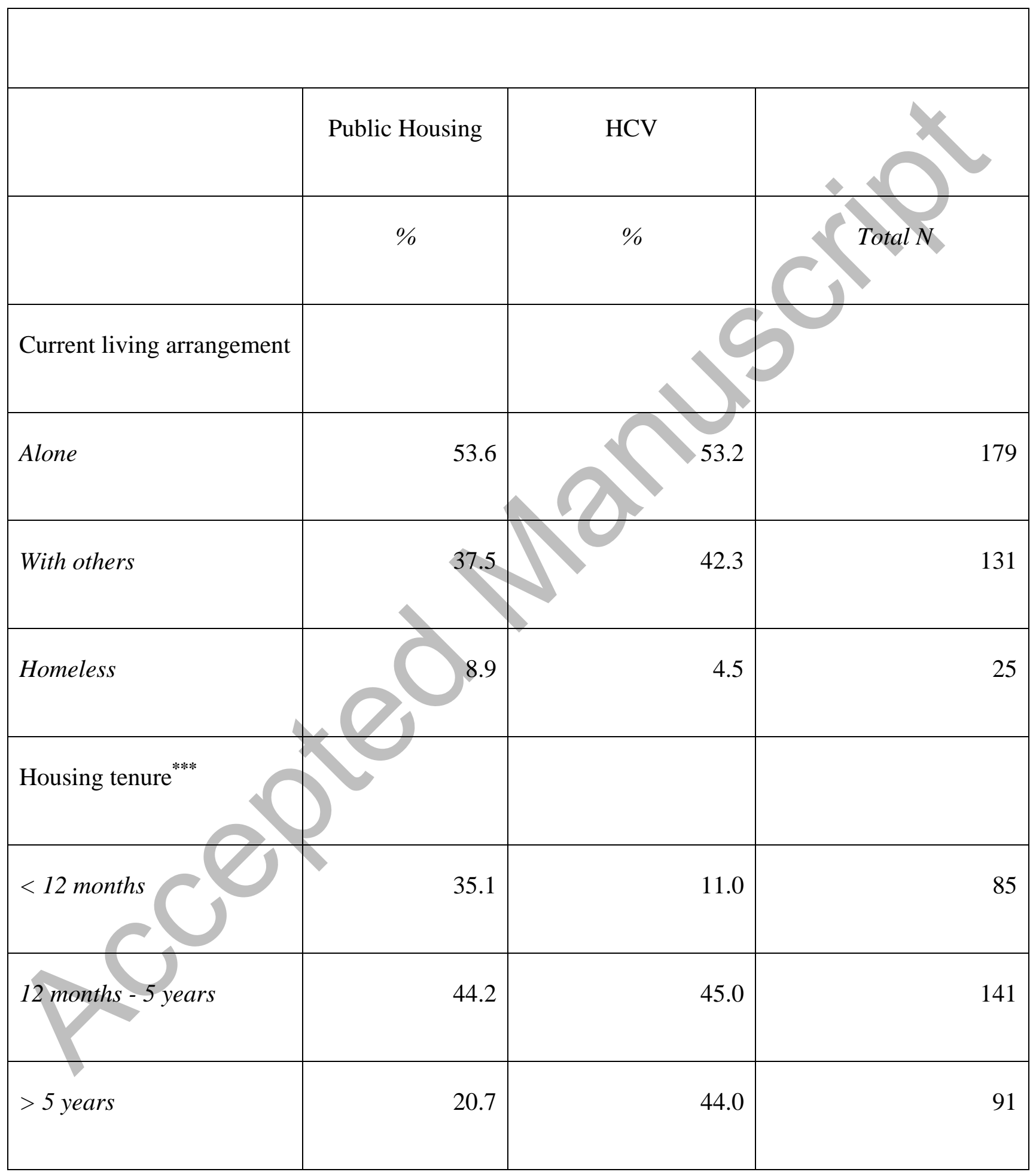




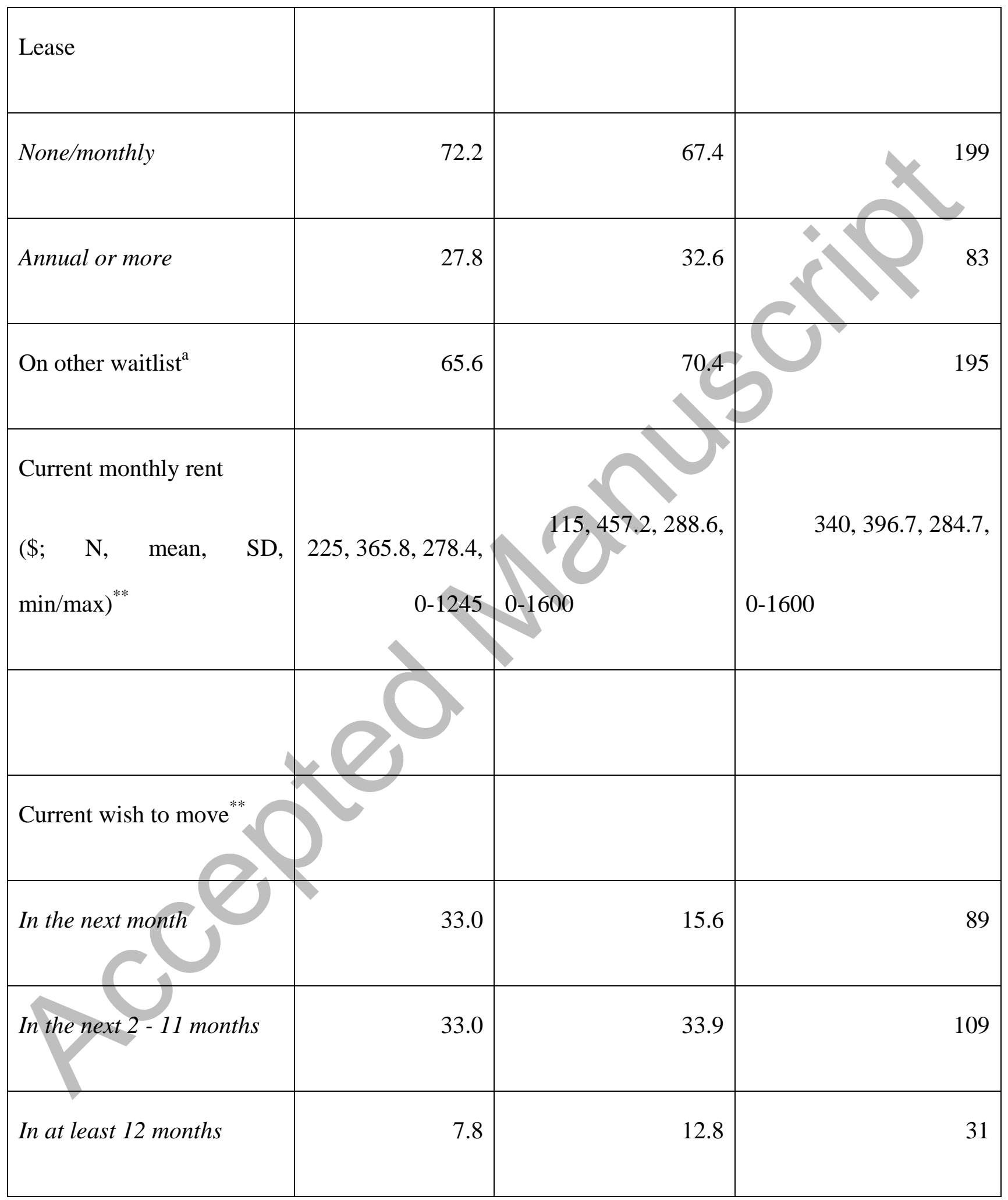




\begin{tabular}{|c|c|c|c|}
\hline Not sure & 19.3 & 24.8 & 69 \\
\hline Not interested in moving & 6.9 & 12.8 & 29 \\
\hline $\begin{array}{l}\text { Preference for senior } \\
\text { housing } 55+^{\mathrm{a}}\end{array}$ & 49.8 & 40.4 & 153 \\
\hline $\begin{array}{l}\text { Preference for senior } \\
\text { housing } 55+\text { w/ services }{ }^{* * a}\end{array}$ & 50.2 & & 146 \\
\hline
\end{tabular}

${ }^{* *} \mathrm{p}<.01 .{ }^{* * *} \mathrm{p}<.001$

${ }^{\mathrm{a}} \chi^{2}=8.13, \mathrm{p}<.004$. Percentages based on respondents who said 'Yes' as compared to respondents who reported 'No' for each item. Percentage 'No' not reported, and percentage 'Not sure’ excluded from analysis. 
Table 3. Risk Characteristics by Application Type

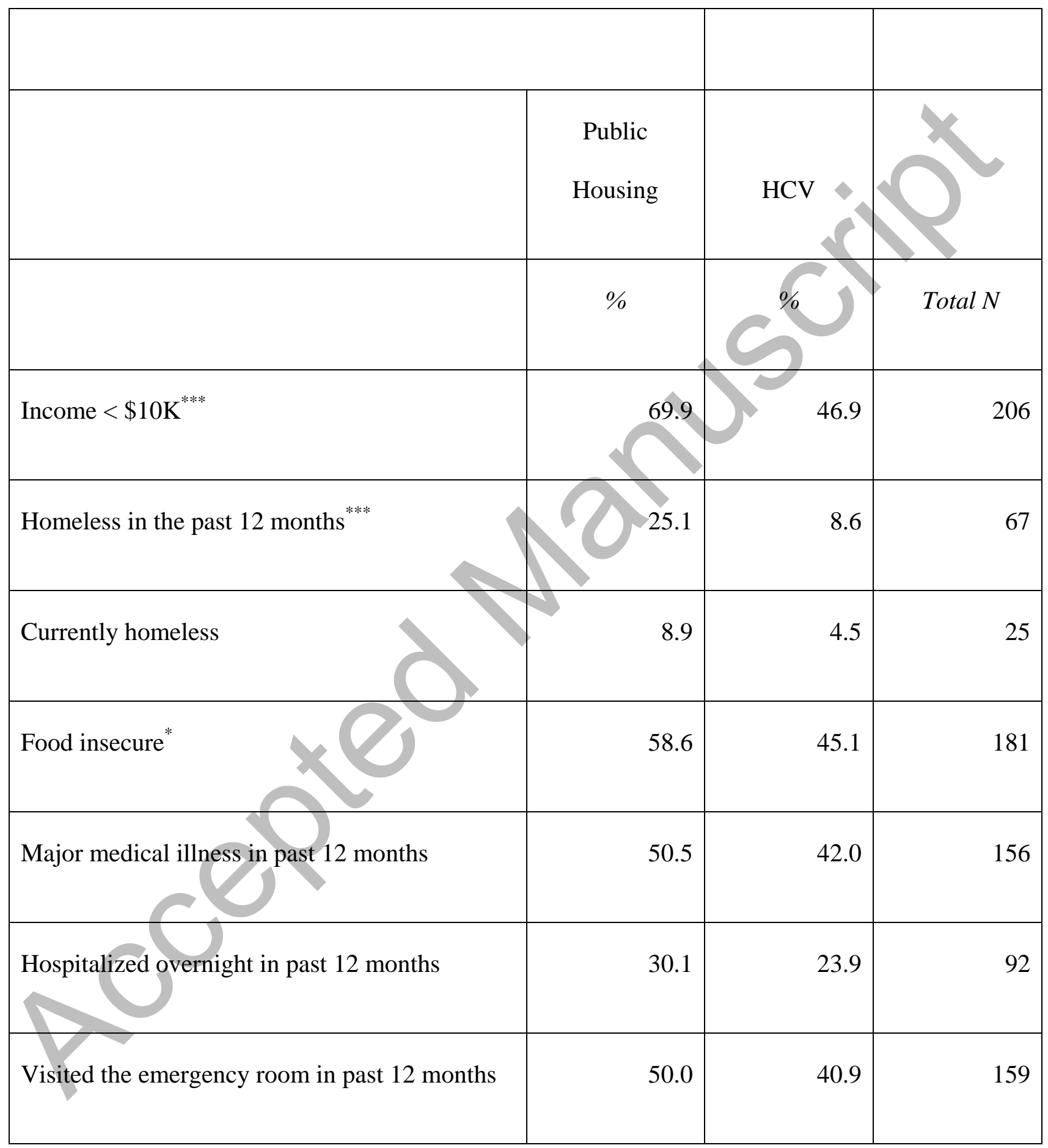




\begin{tabular}{|c|c|c|c|}
\hline Without health insurance in the past 12 months ${ }^{*}$ & 24.3 & 14.0 & 71 \\
\hline Fair/poor health & 58.8 & 52.2 & 193 \\
\hline$>75$ years of age ${ }^{* *}$ & 5.8 & & 31 \\
\hline Living alone & 53.6 & 53.2 & 179 \\
\hline Female & & 57.9 & 199 \\
\hline
\end{tabular}

'Percentages based on respondents who said 'Yes' as compared to respondents who reported 'No' for each item for all variables. Percentage 'No' or otherwise are not reported. 
Table 4. Multiple Logistic Regression Analysis of Waitlist Housing Type

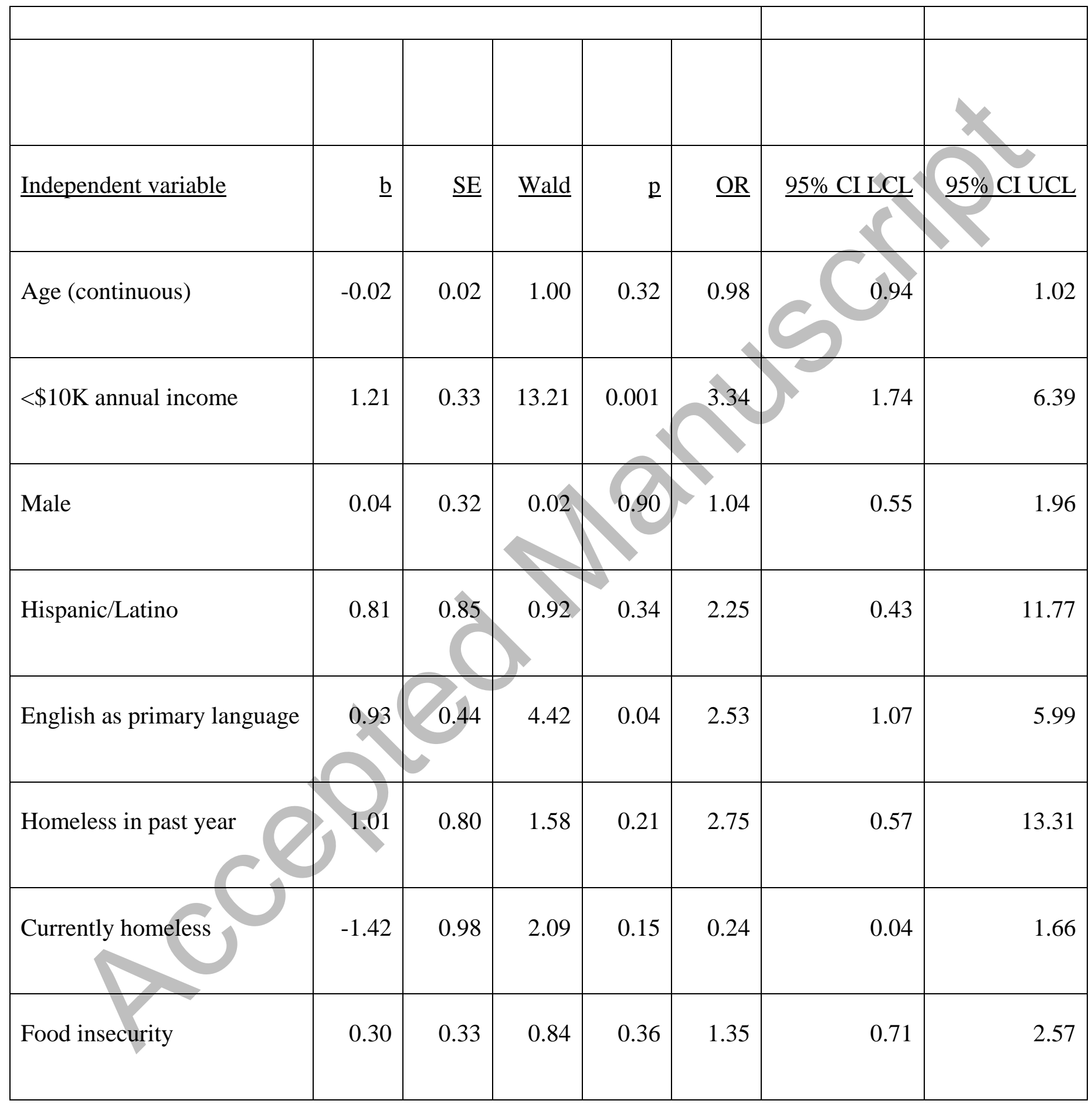




\begin{tabular}{|c|c|c|c|c|c|c|c|}
\hline Medical illness in past year & 0.22 & 0.46 & 0.23 & 0.63 & 1.25 & 0.51 & 3.04 \\
\hline Hospitalized in past year & -0.06 & 0.49 & 0.01 & 0.91 & 0.94 & 0.36 & 2.49 \\
\hline ER visit in past year & 0.35 & 0.46 & 0.57 & 0.45 & 1.42 & & 3.52 \\
\hline $\begin{array}{l}\text { Uninsured at any point in } \\
\text { past vear }\end{array}$ & 0.38 & 0.43 & 0.80 & 0.37 & & 0.64 & 3.36 \\
\hline Self-rated health* & -0.07 & 0.18 & 0.14 & & 0.94 & 0.66 & 1.32 \\
\hline Any social support & 0.02 & 0.36 & 0.00 & 0.95 & 1.02 & 0.51 & 2.05 \\
\hline Other race, non-White & & & 0.40 & 0.53 & 0.81 & 0.43 & 1.54 \\
\hline \multicolumn{8}{|l|}{ Intent to move** } \\
\hline Unsure about $n$ & -0.88 & 0.44 & 3.90 & 0.05 & 0.42 & 0.18 & 0.99 \\
\hline Move within year & -0.95 & 0.42 & 5.11 & 0.02 & 0.39 & 0.17 & 0.88 \\
\hline & & & & & & & \\
\hline
\end{tabular}




\begin{tabular}{|l|l|l|l|l|l|l|l|}
\hline Model $\mathrm{X}^{2}=44.25$ & & & & & & & \\
\hline Nagelkerke $\mathrm{R}^{2}=24.2 \%$ & & & & & & & \\
\hline $\mathrm{n}=229$ & & & & & & & \\
\hline
\end{tabular}

Dependent variable: Application type $-1=$ Public housing, $0=\mathrm{HCV}$

*Self rated health (scale): 1 = excellent, 5 = poor

**As compared to those who want to move within a month 